\title{
UJI AKTIVITAS EKSTRAK BIJI SELASIH (Ocimum basilicum L.) DENGAN BEBERAPA PELARUT SEBAGAI ANTIPIRETIK PADA MENCIT (Mus musculus)
}

\author{
Sitti Rahimah, Wahyu Hendrarti, Sitti Ramlah \\ Sekolah Tinggi Ilmu Farmasi Makassar \\ Email : st_rahima@yahoo.com.
}

\begin{abstract}
Seeds basil (Ocimum basilicum L.) has been known to the publicand is widely used to treat a variety of diseases. One of its benefits as lowering fever but have not been proven scientifically. This study was to determine whether there is an antipyretic effecte basil seeds (Ocimum basilicum L.) and to determine the effectiveness of extracts of basil seeds by using some of the solvent is $n$-hexane, ethyl acetate and ethanol compared with paracetamol in mice (Mus musculus). This study was an experimental study using RAL. Experimental animals used were 15 mice, stages of research giving treatment af mice in each group who had fasted for 12 hours, measured rectal temperature (initial temperature), then injected with $1 \mathrm{ml}$ peptone/tail subcutaneously. The data obtained were analyzed ANOVA followed BNJ test. Test antipyretic extract basil seeds (Ocimum basilicum) with some solvent, most effectively used as a solvent in the basil seeds that solvent ethyl acetate compared with solvent $n$-hexane and ethanol. The results oft his study showed that the extract of basil seeds antipyretic effect.
\end{abstract}

Key words : Seeds basil, Ocimum basilicum, Antipyretics, Mus musculus.

\section{PENDAHULUAN}

Indonesia yang beriklim tropis merupakan salah satu negara terbesar di dunia yang kaya akan keanekaragaman hayati. Di Indonesia tersedia sekitar 30.000 spesies tanaman (Dalimartha, 2008). Lebih dari 1000 spesies tumbuhan dapat dimanfaatkan sebagai bahan baku obat. Tumbuhan tersebut menghasilkan metabolit sekunder dengan struktur molekul dan aktivitas biologik yang beraneka ragam dan memiliki potensi yang sangat baik untuk dikembangkan menjadi obat berbagai penyakit sehingga dikenal dengan obat tradisional (Maksum R, 2005).

Kelebihan pengobatan dengan menggunakan ramuan tumbuhan secara tradisional tersebut selain tidak menimbulkan efek samping, juga tumbuhan-tumbuhan tertentu mudah didapat di sekitar pekarangan rumah, serta mudah dibuat. Proses pengolahan obat tradisional pada 
Uji aktivitas ekstrak biji selasih (Ocimum basilicum L.) dengan beberapa pelarut sebagai antipiretik pada mencit (Mus musculus)

umumnya sangat sederhana, diantaranya ada yang diseduh dengan air, dibuat bubuk kemudian dilarutkan dalam air, ada pula yang diambil sarinya. Cara pengobatan pada umumnya dilakukan peroral (diminum) (Pudjarwoto et al. 1992). Obat tradisional Indonesia masih sangat banyak yang belum diteliti, khususnya yang sebagian besar berasal dari bahan tumbuhan.

Selasih (Ocimum Basilicum L) merupakan tanaman yang banyak ditemukan di negara-negara tropis seperti Indonesia. Bagian-bagian dari selasih yang dapat dipergunakan sebagai bahan obat yaitu biji, batang, tangkai dan bunga. Salah satu khasiat dari selasih sebagai obat tradisonal adalah sebagai antipiretik (penurun demam) namun belum ada data ilmiah terhadap khasiatnya tersebut, selain itu juga biji selasih bisa digunakan untuk meredakan muntah-muntah, mengobati cacingan, batuk, luka, bengkak dll (Kardinan,2003)

\footnotetext{
Demam mengacu pada peningkatan suhu tubuh yang berhubungan langsung dengan tingkat sitokin pirogen yang diproduksi untuk mengatasi berbagai rangsang, misalnya terhadap toksin bakteri, peradangan, dan ransangan pirogenik
}

lain. Bila produksi sitokin pirogen secara sistemik masih dalam batas yang dapat ditoleransi maka efeknya akan menguntungkan tubuh secara keseluruhan, tetapi bila telah melampaui batas kritis tertentu maka sitokin ini membahayakan tubuh. Batas kritis sitokin pirogen sistemik tersebut sejauh ini belum diketahui. (Sherwood, 2001). selasih memiliki berbagai macam kandungan senyawa kimia yang bersifat polar dan non polar sehingga dengan alasan ini digunakan beberapa macam pelarut yaitu etil asetat, etanol, dan n-heksan untuk menguji aktivitas dari biji selasih sebagai obat antipiretik.

Tujuan penelitian ini untuk mengetahui apakah ekstrak biji selasih (Ocimum basilicum L) memiliki aktifitas dan efektifitas dengan menggunakan beberapa pelarut pada mencit (Mus musculus).

\section{METODE PENELITIAN}

\section{Alat dan Bahan}

Alat yang digunakan antara lain timbangan analitik, pipet volume, termometer, spoit, kanula, blender.

Bahan-bahan yang digunakan air suling, pepton, etil asetat, nheksan, etanol, paracetamol, biji selasih, natrium CMC, alkohol, dan mencit sebagai hewan uji. 
Uji aktivitas ekstrak biji selasih (Ocimum basilicum L.) dengan beberapa pelarut sebagai antipiretik pada mencit (Mus musculus)

\section{Prosedur kerja}

\section{Penyiapan Sampel Penelitian}

Sampel penelitian yang digunakan adalah biji selasih.

\section{Pembuatan Ekstrak biji Selasih}

Sebanyak 500 gram biji selasih (Ocimum basilicum L) di ekstraksi dengan metode maserasi. Cairan pengekstraksi masing-masing terdiri dari etanol, etil asetat, dan n-heksan dimasukkan kedalam bejana maserasi, disimpan ditempat yang terhindar dari sinar matahari selama 3 hari sambil dilakukan pengadukan beberapa kali (minimal 2 kali sehari). Filtrat dikentalkan menggunakan rotary vacuum evaporator sehingga diperoleh ekstrak kental.

\section{Pembuatan larutan pepton $\mathbf{1 2 , 5} \%$}

Larutan pepton $12,5 \%$ dibuat dengan menimbang 2 gram pepton yang dilarutkan dalam $20 \mathrm{ml}$ aquadest, dimasukkan kedalam gelas piala 100 $\mathrm{ml}$ sambil diaduk pada suhu $80^{\circ} \mathrm{C}$. Dimasukkan kedalam tabung reaksi, kemudian disterilkan di dalam autoklaf.

Pembuatan Na-CMC 1\% (Parrot, 1979)

Sebanyak $50 \mathrm{ml}$ aquadest panas (700 C) dimasukkan Na CMC sebanyak 1 gram sedikit demi sedikit sambil diaduk hingga terbentuk larutan koloidal. Volume dicukupkan dengan air suling hingga $100 \mathrm{ml}$ dalam labu takar.

\section{Pembuatan suspensi paracetamol}

Suspensi paracetamol $500 \mathrm{mg}$ dibuat dengan menimbang sebanyak 10 tablet paracetamol kemudian dihitung bobot rata-rata tiap tablet dan ditimbang serbuk paracetamol yang setara dengan $2 \mathrm{mg}$. Dimasukkan dalam lumpang dan di gerus. Ditambahkan Na CMC 1\% b/v sedikit demi sedikit sambil digerus hingga homogen lalu dimasukkan dalam labu takar $100 \mathrm{ml}$ dan volumenya dicukupkan dengan $\mathrm{Na}$ CMC 1\% hingga $100 \mathrm{ml}$.

\section{Pemilihan dan Penyiapan Hewan uji}

Dipilih mencit yang sehat dengan bobot badan antara 20-30 gram. Diambil sebanyak 15 ekor dan dikelompokkan dalam 5 kelompok masing-masing terdiri dari 3 ekor mencit.

\section{Pengujian Efek antipiretik Ekstrak} Biji selasih

Lima belas ekor mencit dibagi menjadi 5 kelompok, masing-masing 3 ekor mencit, semua kelompok dipuasakan selama 8-12 jam kemudian diukur suhu rectal awalnya selanjutnya diinduksi pepton 12,5\%, setelah 30 menit kemudian diukur kembali suhu rektalnya. Selanjutnya untuk kelompok I, diberikan air suling. 
Uji aktivitas ekstrak biji selasih (Ocimum basilicum L.) dengan beberapa pelarut sebagai antipiretik pada mencit (Mus musculus)

Untuk kelompok II, III, dan IV masingmasing diberikan ekstrak etanol 10, ekstrak n-heksan 10\% dan ekstrak etil asetat 10\%, Sedangkan untuk kelompok $\mathrm{V}$ diberikan suspensi paracetamol $2 \mathrm{mg} / 30 \mathrm{kgBB}$.

\section{Analisis data}

Data suhu rektal mencit tiap kelompok dirata-ratakan dan dianalisa dengan menggunakan uji statistik rancangan acak lengkap ( RAL ).

\section{HASIL PENELITIAN}

Tabel 1. Hasil rata-rata pengamatan Pengukuran Suhu Tubuh Mencit (Mus musculus)

\begin{tabular}{lccccc}
\hline Perlakuan & $\begin{array}{c}\text { Suhu } \\
\text { Awal }\left({ }^{\circ} \mathbf{C}\right)\end{array}$ & $\begin{array}{c}\text { Suhu } \\
\text { Demam }\left({ }^{\circ} \mathbf{C}\right)\end{array}$ & $\begin{array}{c}\text { Kenaikan } \\
\text { suhu }\left({ }^{\circ} \mathbf{C}\right)\end{array}$ & $\begin{array}{c}\text { Suhu Setelah } \\
\text { Perlakuan }\end{array}$ & $\begin{array}{c}\text { Penurunan } \\
\text { suhu }\left({ }^{\circ} \mathbf{C}\right)\end{array}$ \\
\hline Na-CMC & 37 & 38,3 & 1,36 & 38,6 & 0,2 \\
N-heksan 10\% & 37,2 & 38,9 & 1,5 & 37,2 & 1,5 \\
Etil asetat 10\% & 38,8 & 38,9 & 2,4 & 37,2 & 1,7 \\
Etanol 10\% & 36,9 & 38,53 & 1,63 & 37,7 & 0,83 \\
Paracetamol & 37,2 & 38,8 & 1,56 & 37,33 & 1,73 \\
\hline
\end{tabular}

\section{PEMBAHASAN}

Hasil penelitian yang telah dilakukan diperoleh data kenaikan suhu rectal pada semua kelompok uji hewan coba mencit setelah di induksi dengan pepton $12,5 \%$. Sedangkan hasil penelitian setelah pemberian ekstrak biji selasih dengan menggunakan pelarut etanol, etil asetat, n-heksan dengan konsentrasi $10 \%$, Natrium CMC dan paracetamol terjadi penurunan suhu badan pada hewan uji setelah induksi.

\section{Penggunaan paracetamol} sebagai pembanding, dimana paracetamol diabsorpsi cepat dan sempurna melalui saluran cerna, terrsebar ke seluruh cairan tubuh. $\mathrm{Di}$ metabolisme oleh enzim mikrosom hati, diekskresi melalui ginjal.(Gan Gunawan. 2007).

Penggunaan pepton sebagai peningkatan kondisi demam pada mencit dilihat dari Penelitian yang telah dilakukan Lisdayanti, 2008; Desianti,2007; Jefri,dkk 2003 yang menggunakan pepton sebagai peningkatan kondisi demam. Pepton merupakan protein digunakan sebagai inducer demam yang akan menyebabkan demam pada mencit. Protein secara berlebihan tidak menguntungkan tubuh. (Almatsier, 2002). Pepton adalah Bio stimulasi alami, yang terdiri dari asam Amino dengan bobot molekular rendah peptida dan asam humic yang berlaku bersama-sama untuk mendukung metabolisme dan mengkatalisasi 
Uji aktivitas ekstrak biji selasih (Ocimum basilicum L.) dengan beberapa pelarut sebagai antipiretik pada mencit (Mus musculus)

proses

pertumbuhan.

(Suwandito,2008).

Proses kehilangan panas melalui kulit dimungkinkan karena panas diedarkan melalui pembuluh darah dan juga disuplai langsung ke fleksus arteri kecil melalui anastomosis arteriovenosa yang mengandung banyak otot. Kecepatan aliran dalam fleksus arteriovenosa yang cukup tinggi (kadang mencapai $30 \%$ total curah jantung) akan menyebabkan konduksi panas dari inti tubuh ke kulit menjadi sangat efisien.

Hasil analisis data secara statistik dengan menggunakan Rancangan Acak Lengkap (RAL) pada sampel ekstrak biji selasih pada taraf kepercayaan 0,05 dan 0,01 diperoleh Fhitung 54,89 dengan Ftabel 3,48 dan 5,98 yang menunjukkan $F$ hitung lebih besar dibanding Ftabel maka dapat disimpulkan bahwa kelima perlakuan memberikan pengaruh beda nyata (signifikan). Karena ada perbedaan nyata, perlu untuk menguji lanjut letak perbedaannya dengan melihat nilai koefisien keseragamannya. Apabila nilai koefisien keseragaman lebih kecil dari $5 \%$ maka dilanjutkan ke uji BNJ (Beda Nyata Jujur).

Pada uji nyata jujur dapat dilihat bahwa untuk ekstrak yang menggunakan pelarut etil asetat memiliki efek yang sangat berbeda nyata dengan kontrol negatif dimana pelarut etil asetat memberikan efek beda nyata lebih baik dibandingkan dengan pelarut $\mathrm{n}$-heksan dan etanol.

Berdasarkan hasil penelitian yang didapat, efek antipiretik dari ekstrak biji selasih ini diduga karena adanya senyawa flavonoid yang terkandung dalam biji selasih. Selasih memiliki kandungan flavanoid. Penelitian Adesokan tahun 2008 membuktikan bahwa flavanoid dapat bersifat antipiretik.

\section{KESIMPULAN}

Berdasarkan hasil penelitian dan analisis data yang telah dilakukan dapat disimpulkan bahwa : Ekstrak biji selasih (Ocimum basilicum L.) dapat berefek sebagai antipiretik pada mencit (Mus musculus). Efek antipiretik yang paling efektif digunakan untuk menurunkan suhu rektal mencit demam yaitu pada ekstrak yang menggunakan pelarut etil asetat.

\section{DAFTAR PUSTAKA}

Adesokan, A.A., Yakubu, M.T., Owoyele, B.V., Akanji, M.A., Soladoye, A.O., Lawal, O., 2008. Effect of Administration of Aqueous and Ethanol Extracts of Enantia chlorantha Stem Bark on Brewer's Yeast Induced Pyresis in Rats. African J. of Biochemistry 2(7):165-169. 
Uji aktivitas ekstrak biji selasih (Ocimum basilicum L.) dengan beberapa pelarut sebagai antipiretik pada mencit (Mus musculus)

Almatsier, S., 2002. Prinsip dasar ilmu gizi. PT. Gramedia Pustaka Utama, Jakarta.

Dalimartha, S., 2008. Atlas tumbuhan obat indonesia jilid 3. Perpustakaan Nasional RI, Jakarta.

Dian, D., 2007. Efek Antipiretik Ekstrak Etanol Daun Dadap Serep (Folia Erythrina lithosperma) Terhadap Mencit Jantan Galur DDY. Bandung.

Gunawan, G.S., 2007. Farmakologi dan terapi edisi 5. Departemen Farmakologi dan Terapeutik FKUI, Jakarta.

Jefri, C., et al., 2003. Uji pembanding Efek Antipiretik Ekstrak Air Dringo (Acorus Calamus L.) dengan Kayu Ules (Helictenes Isora L.) Pada Marmut Jantan Demam Akibat Induksi Pepton. Universitas Surabaya, Surabaya.

Kardinan, A., 2003. Selasih : Tanaman
Keramat Multi Manfaat. Agromedia, Jakarta.

Lisdayanti. 2008. Uji Daya Antipiretik Ekstrak Daun Belimbing Wuluh (Averrhoa bilimbi L.) Terhadap penurunan Suhu Rektal Mencit (Mus musculus) Betina.(skripsi)

Maksum, R., 2005. Peranan Bioteknologi dan Mikroba Endofit Dalam Perkembangan Obat Herbal. Maj. IImu Kefarmasian Indonesia

Pudjarwoto,T., Simanjuntak, C.H., Nur, I.P., 1992. Daya Antimikroba Obat Tradisional Diare terhadap Beberapa Jenis Bakteri Enteropatogen. Cermin Dunia Kedokteran 76.

Sherwood, L., 2001. Fisiologi Manusia;dari Sel ke Sistem. Edisi 2. Jakarta.

Suwandito. $2008 . \quad$ Pepton. Http:www/Haifachem.com. Diakses tanggal 11 Juni 2008. 